\title{
Combination of Innovative Thinking with Accounting Teaching
}

\author{
Yi Tang \\ Guangdong University of Science and Technology \\ Dongguan, China 523083
}

\begin{abstract}
Accounting education in colleges teaches knowledge and skills of accounting major and cultivates talents with humanistic feelings, critical and innovative thinking and honesty. It is the original intention of college education that is different from training institutions. Innovation is the first power that leads development and the requirement of accounting practice. Accounting education must highlight the cultivation of innovative thinking. Basic paths that integrate innovative thinking with accounting teaching are proposed according to typical problems in front line of finance and accounting teaching, demands of financial practice in the future and characteristics of accounting.
\end{abstract}

Keywords-innovation; accounting teaching; combination

\section{INTRODUCTION}

Accounting refers to the management science that researches collection, analysis, record, report, explanation and verification of accounting information and effectively manages economy, consists of accounting theory that explains accounting system and the accounting procedure and method that deal with and organize accounting practice ${ }^{1}$. Accounting education is the process that teachers of accounting major cultivate educatee who behave and do things with accounting philosophy and innovation through teaching basic theories, skills and methods of accounting [1]. The core contents cover educational concept, educational objectives and training mode [2].

Concept is related to philosophy (Barnett, 1999), referring to subjects' comprehensive and abstract understanding of objects (Han Yanming, 2003). Educational concept is the core value followed by education activities (Li Tingting, 2010). Luan Fugui (2013) describes educational concept of accounting as rational knowledge and concept system taught by educators in accounting education. Its connotation is concluded as concept system centering on funds movement with economic, managing, cultural, symbolic and philosophical nature, abstract and specific characteristics [1]. The connotation of accounting education and educational concept of accounting contains specialty literacy of accounting and "education of people". Existing researches emphasize the

Project: The staged achievements of provincial major scientific research project in universities of Guangdong (2015GXJK163)

(1) Come from the explanation of National Standard for Teaching Quality of Undergraduate Accounting Major proposed by University Accounting Teaching Committee of the Ministry of Education in August 2014 combination of "do things" and "behave". However, accounting education in reality attaches importance to "do things", namely, teaches knowledge and skills in accounting major, and thinks little of "behave", namely, neglects the education of morality and humanistic feelings. It is very difficult to integrate "Do things" with "behave".

\section{ACCOUNTING CONCEPTS}

Accounting refers to the management science that researches collection, analysis, record, report, explanation and verification of accounting information and effectively manages economy, consists of accounting theory that explains accounting system and the accounting procedure and method that deal with and organize accounting practice ${ }^{(2)}$. Accounting education is the process that teachers of accounting major cultivate educatee who behave and do things with accounting philosophy and innovation through teaching basic theories, skills and methods of accounting [1]. The core contents cover educational concept, educational objectives and training mode [2].

Concept is related to philosophy (Barnett, 1999), referring to subjects' comprehensive and abstract understanding of objects (Han Yanming, 2003). Educational concept is the core value followed by education activities ( $\mathrm{Li}$ Tingting, 2010). Luan Fugui (2013) describes educational concept of accounting as rational knowledge and concept system taught by educators in accounting education. Its connotation is concluded as concept system centering on funds movement with economic, managing, cultural, symbolic and philosophical nature, abstract and specific characteristics [1]. The connotation of accounting education and educational concept of accounting contains specialty literacy of accounting and "education of people". Existing researches emphasize the combination of "do things" and "behave". However, accounting education in reality attaches importance to "do things", namely, teaches knowledge and skills in accounting major, and thinks little of "behave", namely, neglects the education of morality and humanistic feelings. It is very difficult to integrate "Do things" with "behave".

\footnotetext{
Come from the explanation of National Standard for Teaching Quality of Undergraduate Accounting Major proposed by University Accounting Teaching Committee of the Ministry of Education in August 2014
} 


\section{A. Current Situation of Accounting Teaching}

1) Traditional accounting treatment easily leads to thinking set

One of the most basic functions of financial accounting is to reflect the monetary capital movement in the past. The forms of funds movement are complicated and differ in thousands of ways. Financial accounting must record funds movement according to uniform rules and reflect it in the account book, making accounting learning and account transaction processing tedious. Especially accounting for industrial manufacturing, learners and employees often face multifarious vouchers and account books. Traditional accounting learners and employers must go through from existing original vouchers to accounting vouchers, from accounting vouchers to account books and from account books to statements. As time passes, they will follow the beaten track and form thinking set.

\section{2) Too utilitarian and overvalue operation}

Accounting has strong applicability, technicality and operability, which is emphasized in teaching. However, accounting teaching overvalues operation and too utilitarian, especially in application-oriented universities and higher vocational colleges. Books for professional qualification examination are taken as textbooks. Books for accounting qualification examination are used as textbooks of courses like Basic Accounting or Accounting Principles, Financial Regulations and Professional Ethics, Accounting Information System. Books for intermediate accounting examination are used as textbooks of courses like Intermediate Financial Accounting and Economic Law; Tax Law, Advanced Financial Accounting, Audit, Financial Management as well as Company Strategy. Even the course arrangement caters to students' requirements in examination. Some encourage students to obtain certificates through promising that students will obtain credits if they obtain vocational technical qualification certificates of accounting on school days.

Assistant teaching materials of professional qualification examination update knowledge fast and embody the newest policies and rules. However, it overstresses rules, operation and how to do and seldom involves background information related to policies and rules. Taking books for examination as textbooks goes against training students' thinking of questioning. Accounting education is increasingly utilitarian and attaches importance to skill training. Talent training patterns in specialist education, undergraduate education and postgraduate education overstresses the training of accounting knowledge and skills. Obtaining accounting certificates becomes "fast channel" of employment (He Yurun, Li Xiaohui; 2013) [3]. Luan Fugui (2013) proposes the accounting education overstresses accounting instead of management, operation instead of principles, rules instead of questioning, bookkeeping instead of report, now instead of history, western concepts instead of local concepts, individuals instead of systems, thing-in-itself instead of environment, skills instead of education (Luan Fugui, 2013) [1].

Some application-oriented universities and junior colleges are more like training institutions, providing many professional courses and few general education curriculums, the class hour of which is reduced. Undergraduates of accounting major resemble tools that can operate and carry out accounting treatment. Accounting has strong applicability. It is understandable to emphasize its operability, but we cannot neglect other aspects. Except for teaching knowledge, more importantly, college education educates people. The most important difference between colleges and training institutions is the training of humanistic feelings, spirit of questioning, criticism and innovation and the shaping of honesty.

\section{3) Paralleled liberal education and professional education}

Professional education only teaches professional knowledge. Professional education and liberal education often "separate". General basic theories, innovative thinking and enterprising spirit are seldom integrated in teaching of professional knowledge. When the total class hours are fixed, increasing class hours of professional courses inevitably needs reducing class hours of basic courses, so it goes against liberal education. On the contrary, increasing class hours of basic courses inevitably needs reducing class hours of professional courses, so it goes against professional teaching. It is easy to attend to one thing and lose another.

4) Inadequate attentions are paid to principle and system of knowledge

Because the accounting teaching overstresses application and operation and pays inadequate attentions to teaching of principles, the accounting knowledge taught is fragmented. Students neither ascend to the source of knowledge nor grasp principles thoroughly. Knowledge is not systematic enough, so it's hard to span from single knowledge to overall knowledge, concreteness to abstract, phenomenon to essence. They don't know how to carry out accounting treatment when environment, conditions and ways of funds movement change. One of the common problems of students is that "they know what it is but fails to know why", seriously restricting the innovative thinking.

According to the National Standard for Teaching Quality of Undergraduate Accounting Major (proposed by University Accounting Teaching Committee of the Ministry of Education in August 2014), the core courses of undergraduate accounting major must include basic accounting (accounting principles), intermediate financial accounting, advanced financial accounting, cost accounting, management accounting, auditing, corporate finance (financial management) and accounting information system. Most contents of basic accounting belong to financial accounting. Intermediate financial accounting and advanced financial accounting are typical financial accounting, the characteristic of which is to provide financial information according to uniform accounting standard and guideline. Cost accounting is taught according to uniform cost method with few change. Auditing involves two "rulers", accounting standard and auditing standard, both of which are uniform. Therefore, when learning these core courses, students easily form "uniform" and "unchanged" thinking set. They don't question and think textbooks and what teachers teach are right. It is pardonable for fresher to behave in this way. However, juniors and sophomores major in accounting and financial management also fail to question and criticize. There is an old 
saying, "To believe everything in books is worse than to have no books at all". Textbooks are compiled by people. Errors occur because of the knowledge of compilers and difficulties in timely updating textbooks. Moreover, teachers sometimes also make mistakes. The phenomenon of no questioning and no criticism widely existing in application-oriented regular colleges and technical colleges is against the original intention of education. Up to 2012, accounting major is provided in 586 universities nationwide. Graduates of accounting major annually exceed 500,000. They stand out in examinations but lack ability of independent thinking and criticism [3].

5) Teachers and students alienate and have interest relationship

Teachers and students alienate and have interest relationship. In order to pursue high attendance rate, teachers often call the roll and threaten students by deducting marks even letting students fail the exam. Students spend money in employing others to attend class for them. They respect teachers before examinations but take teacher as a passer-by after examinations. The feeling that "he who teaches me for one day is my father for life" has been all gone. Just as the senior professor of Peking University Qian Liqun says, our universities cultivate shrewd egoists why have high intelligence quotient, worldly and adept in acting ${ }^{3}$.

\section{B. Realistic Demand of Cultivating Innovative Thinking}

1) Ever-changing economic environment and accounting practice require advancing with the times and the innovative ideas

With technological progress, economic and social development and integration and innovation of business model, new transaction ways and mode of payment emerge in endlessly, and the reality is virtualized. The "online" and "offline" integration makes traditional outdated accounting treatment difficult to adapt. In order to provide real financial information, we must carry out accounting treatment through seeing through the appearance to perceive the essence of economic transaction. For example, the prompt reply of transfer information between bank accounts, more convenient alipay and WeChat Pay make traditional accounts lose the value of existence, and the account checking in the end of term meaningless.

With changes of economic development model and management forms of enterprises, continuous innovation of business model and transaction ways as well as more diversified funds movement, accounting record that reflects funds movement will be more complicated. Without knowledge of economy and law, people cannot carry out accounting treatment correctly. Traditional teaching that supplies discipline knowledge should transform into the teaching that carries out accounting education and cultivates innovation ability, in order to stimulate students to establish innovative thinking and improve innovation ability through application of discipline knowledge, and meet the social

\footnotetext{
(3) Degraded University: Students Are Utilitarian and Teachers Muddle Along, SOHU Education [EB/OL].

http://learning.sohu.com/20170516/n493166450.shtml.
}

demands for innovation ability of human resources of economic management [4]. According to the research of Kavanagh and Drennan (2008), employers expect graduates of economic management to have solid specialty foundation and commercial awareness, interdisciplinary knowledge and skills to solve comprehensive problems and deal with interpersonal relationship. Innovative thinking is the foundation to form and develop general skills.

2) Future vocational development requires the cultivation of innovative, comprehensive and coordinated ability

Management information is the foundation of accounting and financial information. Management information is dispersed in functional departments and transferred to finance department through original evidences, through which financial staffs identify economic transaction and carry out accounting treatment. Under the accounting computerization at present, improving degree of automation in accounting treatment depends on completion of basic information of enterprises and coordination of functional departments. The higher the automation degree of enterprises, the higher the integration degree of enterprise information will be. Functional departments require being more coordinated. In the information age, the management information and financial information of enterprises have closer relationship and require high degree of integration, in order to realize efficient circulation of enterprise information and integration of enterprise resources.

Finance department depends on business vouchers of other functional departments to carry out accounting treatment, so it has to deal with the relationship with other departments. Meanwhile, it has to timely report comprehensive financial information to enterprise senior. Therefore, competent financial staff must have communication skills.

With the strongest ability of accounting treatment, people are only qualified to serve as accountant officer and accounting manager. In order to become $\mathrm{CFO}$ and have bigger vocational development, the ability of accounting treatment is only one aspect. It requires abilities in communication, coordination, integration and decision making. Liu Guowu, Chen Shaohua and Jia Yinfang (2005) bring critical thinking in accounting teaching and propose that accounting teachers should adopt different strategies in classroom teaching of accounting, in order to train students' critical thinking and ability to solve problems. Wu Zhongchun (2009) proposes problems in accounting education in ability-oriented universities and addresses university accounting teaching mainly cultivates students' ability of continuous learning, analyzing and judging environment and independently dealing with uncertainties.

3) Functional orientation of accounting education at home and abroad

IAESB subordinate to IFAC provides international standard for accounting education and training of professional accountant through issuing IES of professional accountant. So far, IAESB issues eight IES in total. No. 3 International Accounting Education Standard-Professional Skill of Professional Accountant (IES3) resolves the competence proposed in the international accounting education standard 
into intellectual skill, technical and functional skills, personal skills, communication skills and organization and business management skills. "Technical and functional skills" is accounting skill [4]. AACSB observes business education (including accounting) should achieve ten goals: effective communication skills, business ethics, and general knowledge of business, critical thinking, effective decision-making skills, ability of solving problems, and ability of integrating different business knowledge, global thinking, team capacity and professional ability [3].

It proposes in the National Standard for Teaching Quality of Undergraduate Accounting Major proposed by University Accounting Teaching Committee of the Ministry of Education in August 2014 that accounting education should train knowledgeable, applied, compound, extraverted and innovative professionals who meet demands of socialist market economy construction, have humanistic quality, scientific spirit and honesty, grasp knowledge and skills of accounting, management, economy, law and computer application, have practical ability and communication skills, competent in business enterprise, financial enterprise, intermediary organ, governmental agencies, public institutions and other departments. Students major in accounting must have basic and professional knowledge of discipline and other related knowledge. Students cultivated in accounting major should grasp management and economic knowledge, establish good and solid knowledge background and have humanistic knowledge in literature, sociology, psychology, history, politics, ethics, philosophy and art.

Accounting education not only teaches accounting knowledge and skills.

\section{4) Necessity of principle and systematic education}

Accounting major needs technologies and skills but technology implies profound principle and why. The basic procedure of financial accounting is from original evidences to accounting voucher to account book to generate the report according to uniform accounting standard. It has background of economics, management, law and culture. Its correctness depends on cultural background of financial staff, knowledge of non-accounting major and professional judgment. For example, the newest revised opinion draft of income emphasizes basic function of trade contract and takes the control transfer of contract object as standard of income recognition. In order to understand the new income standard, we need knowledge of economics and law. The income recognition in practice requires professional judgment of staff related to accounting treatment.

Although since 1999, accounting major has been classified from economics to management and has become the secondary discipline subordinate to business administration and the degree changes from economics to management, basic theories in economics like funds movement, law of value, value judgment, supply-demand relationship, cost, price, profit, production, exchange, distribution and consumption are theoretical basis of accounting. Researching teaching law of accounting based on economics and establishing the idea of system thinking and divergent thinking will train students to understand the cause and effect of accounting knowledge and their system thinking [1]. Accounting Research, the top academic journal at home, belongs to economic category in the classification of CSSCI. It reflects accounting belongs to economics.

Therefore, professional qualification certificate examination of accounting not only includes accounting knowledge. Junior accountant qualification examination includes Elementary Economics Law. Accountant examination includes Financial Management and Economic Law. The CPA examination includes Accounting, Tax Law, Economic Law, Financial Management, Corporate Strategy and Risk Management.

As the theoretical and method system that systematically researches practical activities of accounting, accounting involves skills and technology and has economic and management nature. Changes of accounting environment such as economic and management situation make accounting become static, dynamic, systematic and exterior digital and information science. Therefore, accounting education should teach accounting knowledge and pay attention to the combination of accounting with general and professional knowledge and emphasize principle, system and extension of knowledge [4].

\section{COMBINATION OF INNOVATIVE THINKING AND ACCOUNTING TEACHING}

Accounting education not only includes skill education, but also includes education in management, economics, thinking, innovation and ethics, including accounting knowledge, accounting thinking, accounting education, accounting innovation as well as organization and management [1]. AACSB observes business education (including accounting) should achieve ten goals: effective communication skills, business ethics, and general knowledge of business, critical thinking, effective decision-making skills, ability of solving problems, and ability of integrating different business knowledge, global thinking, team capacity and professional ability [3]. Wen Meiqin and Tao Xiaomin (2015) propose we should integrate international educational thought and requirements in accounting education to train and improve students' innovative spirit and ability, and observe the combination of humanistic education with professional knowledge education is the basic change of educational thought, educational concept and educational system [5]. Accounting education trains talents who know something of everything and everything of something, namely the accounting professionals with solid foundation and extensive knowledge (Wang Guangyuan, 1999) [6].

Accounting education trains skills and how to behave. Innovative thinking involves doing things and behaving. Educators related to theory and practice of accounting education should research how to integrate innovative thinking in teaching and learning of basic knowledge, theory and skills of accounting, in order to meet ever-changing demands of accounting practice. 


\section{A. Teach Principles}

First, learn accounting standards and experience its principles. Accounting standard is the standard of financial accounting and a "ruler" of accounting treatment. It is principle orientation and applicable to different industries and enterprises. The revise of accounting principle embodies the characteristic. The principle orientation contains profound accounting principle. However, accounting education seldom involves standard. Teachers often mention the accounting standard involved at the beginning of one chapter but seldom thoroughly explain it. In most cases, they teach specific cases and mechanically teach students debit and credit. Students neither understand accounting standard nor correctly carry out accounting treatment. Since financial accounting means carrying out accounting treatment under the guidance of accounting standard, accounting teaching must learn accounting standard, correctly explain it and its nature as well as grasp its principles. Learning accounting standard is to learn standard, analyze its principle and understand the spirit of "remaining essentially the same despite all apparent changes".

Second, learn background and historical changes of introduction of accounting policies, standards, laws and regulations. The introduction of accounting policies and regulations has historical background, which helps us truly understand its nature and arouses our interests in tracing the source. For example, why the change of book value resulted from the change of fair value of financial assets available for sale isn't written in profit and loss subject "changes in fair value recognized in profit or loss" but written in owner's equity; it was written in "capital reserve-other" but no written in "other comprehensive income". The changes of accounting policies and the profound historical background make us thoroughly understand and grasp accounting treatment.

Third, teach through finding by hard and thorough search. Teachers should impart moral ideas, teach professional knowledge and solve problems. Teachers and students should not have a smattering of knowledge but find by hard and thorough search and achieve mastery through comprehensive study. They should think why different processing modes exist for similar business transaction. As provision for diminution in value, why bad-debt provision and inventory falling price reserves can reverse but provision for diminution in value withdrawn by long-term asset cannot reverse. Guiding students to think and search literature through questioning can improve students' interests and train their thinking of questioning and research. Students will know the introduction of accounting policies has profound historical background. Accounting has profound social property and is influenced by social environment as well as national cultural, economic, social and technological development.

\section{B. Teach through Combination of Principle and Flexible Application}

Accounting standard is the "ruler" of accounting treatment and refers to norm in principle. According to recent revise of international accounting standard, American accounting standard and domestic accounting standard, it is principle orientation and seldom involves specific practical guidance. For example, IASB and FASB launched a joint project, issuing
No. 15 International Financial Reporting Standard-Revenue from Customer Contract and Topic606-Revenue from Customer Contract respectively in May 2014. Two standards of No. 18 International Accounting Standard-Revenue (IAS18) and No.11 International Accounting StandardConstruction Contract (IAS11) are unified. Referring to IFRS15, in December 2015, our country printed and distributed No.14 Accounting Standards for Business Enterprises-Revenue (Revise) (Exposure Draft)) (CBK [2015] No. 24), and required implementing the newly revised Revenue Standard from January 1, 2018. No. 14 Accounting Standards for Business Enterprises-Revenue and No. 15 Accounting Standards for Business Enterprises-Construction Contract are unified, carrying out more unified specification of revenue recognition of sales and construction contracts. The reason why the revise of accounting standard tends to principle guidance instead of practical guidance is that the environment, conditions and transaction modes are different. Practical guidance is difficult to normalize different practices. It will at loose ends when emerging industries, specific industries and special services appear.

Accounting has strong social property, so it has regional characteristics. Different culture in different regions will lead to different accounting concepts and behavioral patterns [7]. Accounting standards only provide basic specification and guidance, because accounting refers to social science and has social property. Under the guidance of accounting standard, we should base on specific environment, characteristics of enterprise and carry out accounting treatment through professional judgment. If the accounting education neither discusses principles nor integrates innovative thinking but teaches some cases, students will fail to understand accounting principles and cannot carry out accounting treatment, will don't know what to do in face of economic practice as well as cannot meet requirements of economic development. Therefore, facing the ever-changing accounting practice, except for case teaching, accounting teaching should integrate innovative ideas, questioning thinking and dialectical thinking, discuss the source and introduce the background and then conclude and summarize.

\section{Heuristic Teaching}

In traditional "duck-stuffing" type of teaching, students passively receive knowledge and simply remember and form fixed thinking. They don't know how to do when environment and conditions change. The teaching model no longer meets demands of modern teaching. Heuristic teaching means stimulating students' interests in exploring knowledge actively. Conditions and knowledge frame is provided. According to the law of development of things, students are guided to think how they should and shouldn't do. One of the basic functions of financial accounting is to reflect funds movement. Accounting standard is the "ruler" to measure whether the accounting treatment is correct. When learning and applying accounting standard, after explaining principles, teachers teach typical cases and guide students to carry out accounting treatment according to principles. Under the guidance of the teacher, in most cases, students can judge and carry out correct accounting treatment. Special treatment can be considered as 
particular case. For example, the teaching of accounting information system cannot mechanically operate according to fixed procedures. Instead, teachers should ask why it designs like this, what the logic is and whether we can optimize to increase efficiency.

\section{Critical Teaching}

One of the functions of college education is to train students' questioning thinking and critical spirit. Teachers should guide students to get rid of the idea that excessively depends on textbooks and teachers. Students question textbooks, criticize and challenge teachers and doubt the rationality of some accounting standards because textbooks, what teachers teach and the formulation of accounting standards are not always right. First, it is improper to advocate critical thinking among freshmen because they are not independent enough, critical thinking may make them dislike textbooks and distrust teachers. Critical teaching can be carried out among sophomore, junior and senior. Second, teach according to students' thinking and then correct and evaluate according to standards and finally propose correct thinking, methods and operation. Third, before revealing the right answers, guide students to propose different ideas and methods, and discuss, analyze, judge and compare with them, choose the best methods to carry out correct accounting treatment. Students go through the process from mistake to correctness and gain enlightenment. Besides, the questioning and critical thinking of them is stimulated.

\section{E. Bring Academic Frontier in Classroom of Accounting}

Teachers should impart moral ideas, teach professional knowledge and solve problems. Meanwhile, they should promote scientific progress and do scientific research. College teachers should teach as well as do scientific research and they must strike a balance between the two. If they teach outdated knowledge, the class may be boring. If they can bring academic frontier in the class, it will make the class vivid, arouse students' curiosity and thirst for knowledge and train their innovative thinking. For example, bringing environment accounting and human resources accounting in class will arouse students' interests, train their innovative thinking and avail academic transmission.

\section{CONCLUSION}

Innovation promotes continuous economic and social development, so education must highlight the cultivation of innovative thinking. According to problems in front line financial and accounting teaching, requirements of future economic development and characteristics of accounting, the basic paths of combination of innovative thinking and accounting teaching are proposed: teach principles; teach through combination of principle and flexible application; heuristic teaching; critical teaching; bring academic frontier in classroom of accounting.

\section{REFERENCES}

[1] Luan Fugui. Accounting Education Concept [J], Accounting Research, 2013(4): 20-25
[2] Liu Guocheng, Dong Birong. Difficulties and Reform of Accounting Education for Undergraduates in China in the "Internet Plus" Era [J], Journal of Nanjing Audit University, 2017, 14(1): 102-109

[3] He Yurun, Li Xiaohui. Research on Training Mode of Accounting Talents in Universities of Our Country: Base on Field Research of Accounting Education in Ten American Universities [J], Accounting Research, 2013(4): 26-31

[4] Wang Yan. Accounting Education Concept and Training of Innovation Ability: Base on Accounting Education of Non-account Majors of Economic Management [J], Accounting Research, 2016(2): 89-94

[5] Wen Meiqin, Tao Xiaomin. Assumption on Innovating Structure of Higher Accounting Education in Our Country [J], Journal of Nanjing University of Finance and Economics, 2005(3): 104-106

[6] Wang Guangyuan, Chen Hanwen, Lin Zhhiyi. Opinions on Objectives of Accounting Education [J], Accounting Research, 1999, (9)

[7] Wu Aili, Wang Kaitian. "The Belt and Road" Strategy and Reform Orientation of Higher Accounting Education in Our Country [J], China Higher Education, 2016(22): 54-56 